\title{
POTENSI SISTEM PERTANIAN ORGANIK DALAM KONSERVASI MUSUH ALAMI HAMA DAN SERANGGA NETRAL PADA TANAMAN SAYURAN DI LAHAN GAMBUT \\ (Potency Of Organic Agricultural System In Conservation Of Natural Energy And Different Environment In Vegetable Plants In Grave Land)
}

\author{
Melhanah ${ }^{1}$, Supriati, L. ${ }^{1}$, dan Saraswati, $D^{1}$ \\ ${ }^{1}$ Fakultas Pertanian Universitas Palangka Raya \\ Telpon : 0811526963 Email: melhanah@yahoo.co.id
}

Diterima : 20/02/2018

Disetujui : 05/05/2018

\begin{abstract}
ABSTRACK
The purpose of this research is to know the potential of organic farming in the conservation of natural enemies of important pests and neutral insects on the ecosystem of sweet corn and long bean vegetables in peatlands Kalampangan Urban Village Palangka Raya. The study was conducted on an area of $210 \mathrm{~m} 2$, divided into 12 plots planted sweet corn and long beans with organic and conventional treatment. Observations were made at 2-8 MST. Samples were taken using sweep nets (for canopy arthropods), pitfall traps (for ground surface arthropods) and light traps (for nocturnal arthropods). The results showed: organic vegetables potentially developed in the effort of conservation of natural enemies and neutral insects with indicators as follows: 1). The number of insects found in organic and conventional plots consists of predators (84.11\%), parasitoids $(8.49 \%)$ and neutral insects $(7.40 \%) ; 2)$. The predator species richness in organic long bean plants is higher than conventional $(\mathrm{R}=2.711$ and 1.811$)$. The predominant predominance of sweet corn and long bean organic plants is Gryllidae $(\mathrm{C}=0.331)$, Formicidae $(\mathrm{C}=0.465)$ and Miridae $(\mathrm{C}=0.109) ; 3)$. The richness of parasitoids and neutral insects in organic sweet corn is higher than conventional $(\mathrm{R}=1,265$ and 1,193). Types of parasitoids and neutral insects dominating organic and conventional vegetables are Braconidae and Scarabaeidae with values 0.444 and 0.423 .
\end{abstract}

Keywords: organic vegetables, natural enemies, neutral insects, pests, peat

\section{ABSTRAK}

Tujuan penelitian untuk mengetahui potensi pertanian organik dalam konservasi musuh alami hama penting dan serangga netral pada ekosistem sayuran jagung manis dan kacang panjang di lahan gambut Kelurahan Kalampangan Kota Palangka Raya. Penelitian dilaksanakan pada lahan seluas $210 \mathrm{~m}^{2}$, dibagi menjadi 12 petak yang ditanami jagung manis dan kacang panjang dengan perlakuan organik dan konvensional. Pengamatan dilakukan pada umur 2-8 MST. Sampel diambil menggunakan jaring perangkap (untuk arthropoda tajuk), perangkap jatuh (untuk arthropoda permukaan tanah) dan perangkap cahaya (untuk arthropoda nokturnal). Hasil penelitian menunjukkan: sayuran organik berpotensi dikembangkan dalam upaya konservasi musuh alami dan serangga netral dengan indikator sebagai beikut :-1). Jumlah serangga yang ditemukan pada petak organik dan konvensional terdiri dari predator $(84.11 \%)$, parasitoid $(8.49 \%)$ dan serangga netral $(7,40 \%) ; 2)$. Kekayaan jenis predator pada tanaman kacang panjang organik lebih tinggi dibandingkan konvensional $(\mathrm{R}=2.711$ dan 1.811). Dominasi predator lebih banyak pada tanaman jagung manis dan kacang panjang organik yaitu Gryllidae $(\mathrm{C}=0.331)$, Formicidae $(\mathrm{C}=0.465)$ dan Miridae $(\mathrm{C}=0.109)$; 3). Kekayaan jenis parasitoid dan serangga netral pada jagung manis organik lebih tinggi dibandingkan konvensional $(R=1.265$ dan 1.193). Jenis parasitoid dan serangga 
netral yang mendominasi sayuran organik dan konvensional adalah Braconidae dan Scarabaeidae dengan nilai 0.444 dan 0.423

Kata Kunci : sayuran organik, musuh alami, serangga netral, hama, gambut

\section{PENDAHULUAN}

Pertanian organik adalah sistem pertanian yang berbasis pada penggunaan residu atau mendaur ulang residu dari kegiatan apa saja di sekitar lahan seoptimal mungkin asalkan memenuhi kriteria (Hairiah, 2003). Tujuan utama pertanian organik adalah menyediakan produk-produk pertanian, terutama bahan pangan yang aman bagi kesehatan produsen dan konsumennya serta tidak merusak lingkungan (Badan Litbang Pertanian, 2002). Ciri pertanian organik adalah penggunaan bahan organik baik dalam pemupukan maupun dalam pengendalian hama dan penyakit.

Pengendalian hama di pertanaman sayuran seperti jagung dan kacang panjang masih mengandalkan penggunaan pestisida kimia . Hasil penelitian Melhanah et all (2015) menunjukkan penggunaan insektisida kimia menyebabkan berkurangnya keanekaragaman arthropoda pada agroekosistem pertanaman kacang panjang, jagung manis dan sawi.

Penggunaan pestisida kimia yang berlebihan dan kurang hati-hati untuk mengendalikan hama menyebabkan masalah hama menjadi lebih banyak dan musnahnya musuh alami seperti parasitoid/predator dan serangga berguna lainnya

(Untung, 2003).

Musuh alami merupakan faktor penting dalam menjaga keseimbangan ekosistem, oleh karena itu keberadaannya perlu dipertahankan dan dilestarikan. Musuh alami tersebut perlu dioptimalkan sebagai agen pengendali alami, antara lain dengan melakukan konservasi agar keberadaan musuh alami tersebut dapat dimanfaatkan secara berkelanjutan. Salah satu alternatif adalah melalui penerapan sistem pertanian organik. Penelitian ini bertujuan untuk mengetahui potensi pertanian organik dalam konservasi musuh alami hama penting dan serangga netral tanaman jagung manis dan kacang panjang.

\section{BAHAN DAN METODE}

Penelitian dilaksanakan selama 4 bulan mulai bulan Agustus sampai November 2016, di Kelurahan Kalampangan Kecamatan Sebangau dan Laboratorium Jurusan Budidaya Pertanian, Fakultas Pertanian, Universitas Palangka Raya.

Penelitian dilaksanakan pada hamparan seluas $210 \mathrm{~m}^{2}$. Lahan tersebut dibagi menjadi 12 petak percobaan (sub plot) yang masingmasing berukuran panjang 4,5 $\mathrm{m}$ dan lebar 3 $\mathrm{m}$, ditanami sayuran jagung manis (6 petak) dan kacang panjang (6 petak). Untuk masingmasing petak percobaan 6 petak dibudidayakan secara organik (menggunakan pupuk kandang kotoran sapi, pupuk organik cair Nasa, insektisida nabati gulma babadotan) dan enam petak lainnya dibudidayakan secara konvensional menurut kebiasaan petani di Kalampangan (menggunakan pupuk kimia sintetik NPK Mutiara, Pupuk green tonik, Pupuk Kandang Kotoran ayam, abu bakaran dari gulma dan disemprot insektisida dengan bahan aktif Tiamedoksan dan Lamda Sihatlorin) jika populasi hama mencapai ambang ekonomi.

Penelitian menggunakan 3 teknik perangkap serangga yaitu perangkap jaring (Sweep Net), perangkap jatuh (Fitfall Trap) dan Perangkap Cahaya (Light Trap). Perangkap jaring untuk menangkap serangga yang aktif pada siang hari, perangkap cahaya untuk menangkap serangga yang respon terhadap cahaya pada malam hari (nokturnal) sedangkan perangkap jatuh untuk menangkap serangga tanah. Arthropoda yang tertangkap dikelola sebagai koleksi kering dan basah dalam alkohol $70 \%$ kemudian diidentifikasi di Laboratorium Jurusan Budidaya Pertanian. 
Perangkap ini menggunakan lampu emergency sebagai sumber cahaya.

Untuk mengetahui potensi pertanian organik dalam rangka konservasi musuh alami penting dan serangga netral dilakukan pengamatan populasi arthropoda di lahan pertanaman jagung manis dan kacang panjang (Margalef ,1958; dan Odum, 1971). Analisis data terdiri atas : 1). Komposisi artropoda (parasit, predator,dan serangga netral); 2). Indeks Kekayayan jenis (R); 3).Indeks Dominansi (C)

Indeks kekayaan jenis (R) dapat dihitung dengan menggunakan rumus yang diadopsi dari Margalef (1958) sebagai berikut:

$\mathbf{R}=\mathbf{S}-\mathbf{1} / \mathbf{l n}(\mathbf{N})$

Keterangan:

$\mathrm{R}=$ indeks kekayaan jenis (indices of species richness)

Kriteria: $\mathrm{R}<2,5$ menunjukkan tingkat kekayaan jenis yang rendah

2,5> $\mathrm{R}>4$ menunjukkan tingkat kekayaan jenis yang sedang

$\mathrm{R}>4$ menunjukkan tingkat kekayaan jenis yang tinggi

$\mathrm{S}=$ jumlah total jenis dalam suatu habitat (species per habitat)

$\ln =$ logaritma natural

$\mathrm{N}=$ jumlah total individu pada suatu habitat (individu per habitat)

Dominansi suatu jenis dalam komunitas dinyatakan dengan besaran C (Odum, 1971), untuk mengukur nilai dominansi dapat menggunakan persamaan sebagai berikut : $\mathbf{C}=\boldsymbol{\Sigma}(\mathbf{n i} / \mathbf{N})^{2}$

$\mathrm{C}=$ Indeks dominansi jenis (Simpson)

$\mathrm{ni}=$ Jumlah individu ke-i

$\mathrm{N}=$ Total nilai penting (jumlah individu seluruh jenis)

HASIL DAN PEMBAHASAN Komposisi artropoda (parasit, predator, serangga pengurai bahan organik, dan serangga netral)

Hasil penelitian selama lima periode pengamatan pada tanaman jagung manis dan kacang panjang petak organik dan konvensional, arthropoda yang tertangkap pada tajuk tanaman (perangkap jaring-/sweep net), permukaan tanah (perangkap jatuh/pitfall trap) dan perangkap cahaya (light trap) diperoleh 8 ordo yang terdiri dari 42 famili dengan jumlah populasi sebesar 743 ekor (Tabel 1). Setelah dikelompokkan diperoleh kelompok predator sebesar $(625$ ekor $(84.11 \%)$ yang terdiri dari 6 ordo, dan 26 famili. Kelompok parasitoid berjumlah 63 $(8,49 \%)$ terdiri dari 2 ordo dan 6 famili, sedangkan kelompok serangga netral diperoleh 55 individu $(7,40 \%)$ yang terdiri dari 4 ordo dan dan 7 famili. Tingginya populasi predator dan parasitoid yang diperoleh mampu mengendalikan hama secara alami. Bila dibandingkan dengan hasil penelitian Murdan dan Sardjan (2009) jumlah famili yang ditemukan juga lebih banyak. Hasil penelitian Murdan dan Sardjan (2009) pada tanaman sayuran yang ditanam secara organik di Lombok Barat diperoleh 15 famili dari kelompok predator dan 8 famili dari kelompok parasitoid.

Kelompok serangga netral adalah serangga yang tidak termasuk dalam serangga parasit atau predator tetapi memikili peran yang berguna seperti serangga pemakan bahan organik, serangga penyerbuk, serangga pengurai bahan organik dan makanan alternatif bagi musuh alami. Jenis yang teridentifikasi selama penelitian dari kelompok pemakan bahan organik adalah lalat (Famili Drosophilidae, Ordo Diptera), Kumbang (Famiili Scarabaeidae dan Dryopidae, Ordo Coleoptera), Kecoa (Famili Blattidae,ordo Orthoptera) dan Rayap (Famili Termitidae dan Rhinotermitidae, ordo Isoptera). Kelompok lainnya adalah serangga penyerbuk yaitu Lebah (Famili Bombidae, ordo Hymenoptera).

Selama 5 periode pengamatan, selalu dijumpai jumlah serangga yang lebih banyak pada petak organik tanaman jagung manis maupun kacang panjang kecuali pada pengamatan ke-4 yaitu fase berbunga dijumpai lebih banyak serangga pada petak konvensional. Pada petak organik jagung 
manis dijumpai lebih banyak kelompok serangga predator ordo Orthoptera famili Grillidae, Ordo Hemiptera famili Gerridae, Hymenoptera famili Formicidae dan Ordo Coleoptera famili Psephenidae. Sedangkan pada petak konvensional jagung manis dijumpai lebih banyak predator dari Ordo Hemiptera famili Miridae, Vellidae dan Reduviidae, dan Hymenoptera famili Apidae. Pada petak organik kacang panjang dijumpai lebih banyak kelompok serangga predator Ordo Hemiptera famili Miridae, Vellidae dan Lycaenidae. Sedangkan pada petak konvensional kacang panjang lebih banyak dijumpai predator dari ordo Orthoptera famili Grillidae, Ordo Hymenoptera famili Formicidae, dan Ordo Coleoptera famili Psephenidae.

Pada petak organik jagung manis dan kacang panjang dijumpai lebih banyak kelompok serangga parasitoid ordo Diptera famili Chloropidae, Ordo Hymenoptera famili Tiphiidae dan Drynidae. Pada petak konvensional jagung manis dan kacang panjang dijumpai lebih banyak kelompok serangga parasitoid ordo Hymenoptera famili Braconidae. Sementara pada petak organik jagung manis dan kacang panjang dijumpai lebih banyak kelompok serangga netral Ordo
Isoptera famili Rhinotermitidae dan Termitidae.

Kekayaan Jenis (R) Predator dan Indeks Dominansi (C) Predator pada Ekosistem Jagung manis dan kacang panjang

Kekayaan jenis predator merupakan indikator banyaknya jenis predator pada suatu ekosistem. Kekayaan jenis predator pada tanaman kacang panjang lebih tinggi pada perlakuan secara organik, dan sebaliknya kekayaan jenis pada tanaman jagung manis lebih timggi pada petak konvensional (Tabel $1)$.

Nilai kekayaan jenis pada tanaman jagung manis organik dan konvensional serta kacang panjang organik tergolong sedang $(2,5>R>4)$, sedangkan pada kacang panjang konvensional menunjukkan tingkat kekayaan jenis yang rendah $(R<2,5)$.

Dominansi pada masing masing tanaman memiliki nilai bervariasi. Pada tanaman jagung manis organik, kelompok predator jangkrik dan semut nilai indeks dominansinya lebih tinggi dibandingkan petak konvensional, sedangkan pada kacang panjang petak organik nilai indeks dominansi kelompok kepik lebih tinggi dibandingkan perlakuan konvensional.

Tabel 1. Struktur komunitas predator, parasitoid dan serangga netral pada tajuk tanaman (TT), permukaan tanah (PT) dan serangga Nokturnal (N) pada ekosistem jagung manis dan kacang panjang

\begin{tabular}{|c|c|c|c|c|c|}
\hline $\begin{array}{l}\text { Kel.Predator } \\
\text { dan Jumlah Famili }\end{array}$ & Lokasi & $\begin{array}{l}\text { Kel. Parasitoid } \\
\text { dan Jumlah } \\
\text { Famili }\end{array}$ & Lokasi & $\begin{array}{l}\text { Kel. Serangga } \\
\text { netral dan Jumlah } \\
\text { famili }\end{array}$ & Lokasi \\
\hline Orthoptera (4) & N,TT,PT & Diptera (1) & PT & Hymenoptera (1) & $\mathrm{N}$ \\
\hline Hemiptera (5) & N,TT,PT & $\begin{array}{l}\text { Hymenoptera } \\
\text { (4) }\end{array}$ & $\mathrm{TT}, \mathrm{N}$ & Coleoptera (2) & $\mathrm{N}$ \\
\hline Diptera (4) & PT,TT & & & Orthoptera (1) & $\mathrm{N}$ \\
\hline Hymenoptera (6) & N,TT,PT & & & Isoptera (2) & $\mathrm{N}$ \\
\hline Odonata (2) & TT & & & Diptera (1) & TT \\
\hline Coleoptera (5) & PT, $N$ & & & & \\
\hline Araneae(2) & $\mathrm{N}, \mathrm{PT}$ & & & & \\
\hline $\begin{array}{l}\text { Jum. Ordo }=6 \\
\text { Jum. Fam. }=26\end{array}$ & & $\begin{array}{l}\text { Jum. Ordo }=2 \\
\text { Jum. Fam. }=5\end{array}$ & & $\begin{array}{l}\text { Jum. Ordo }=5 \\
\text { Jum. Fam. }=7\end{array}$ & \\
\hline TOTAL ORDO & & & & & 8 \\
\hline TOTAL FAMILI & & & & & 42 \\
\hline TOTAL INDIVIDU & & & & & 743 \\
\hline
\end{tabular}


Tabel 2. Indeks Kekayaan Jenis (R) Predator dan Dominansi (C) beberapa kelompok predator pada tajuk tanaman (TT), permukaan tanah (PT) dan serangga Nokturnal (N) pada ekosistem jagung manis dan kacang panjang yang dibudidayakan secara konvensional dan organik

\begin{tabular}{lcccc}
\hline \multirow{2}{*}{ Indeks R dan C Predator } & \multicolumn{2}{c}{ Jagung Manis } & \multicolumn{2}{c}{ Kacang Panjang } \\
\cline { 2 - 5 } Indeks Kekayaan jenis (R) & Organik & Konvensional & Organik & Konvensional \\
Indeks Dominansi (C) & 2.783 & $\mathbf{3 . 0 0 0}$ & $\mathbf{2 . 7 1 1}$ & 1.811 \\
1. Kel. Jangkrik (Gryllidae) & & & & \\
2. Kel. Kepik (Miridae) & $\mathbf{0 . 3 3 1}$ & 0.273 & 0.157 & 0.162 \\
3. Kel. Semut (Formicidae) & 0.001 & 0.008 & $\mathbf{0 . 1 0 9}$ & 0.001 \\
\hline
\end{tabular}

Tabel 2. Indeks Kekayaan Jenis (R) Parasitoid serta Dominansi Serangga netral pada tajuk tanaman (TT), permukaan tanah (PT) dan serangga Nokturnal (N) (C) kelompok kumbang pada pada ekosistem jagung manis dan kacang panjang yang dibudidayakan secara konvensional dan organik

\begin{tabular}{lcccc}
\hline \multicolumn{1}{c}{$\begin{array}{c}\text { Indeks R dan C Parasitoid } \\
\quad \text { dan Serangga netral }\end{array}$} & \multicolumn{2}{c}{ Jagung Manis } & \multicolumn{2}{c}{ Kacang Panjang } \\
\cline { 2 - 5 } $\begin{array}{l}\text { Indeks Kekayaan jenis (R) } \\
\text { Indeks Dominansi (C) }\end{array}$ & 1.265 & 1.193 & 1.519 & 1.919 \\
$\begin{array}{l}\text { Parasitoid Kel Tabuhan } \\
\text { (Braconidae) }\end{array}$ & 0.003 & 0.444 & 0.105 & 0.235 \\
$\begin{array}{l}\text { Indeks Dominansi (C) serangga } \\
\text { netral Kelompok Kumbang }\end{array}$ & 0.003 & 0.147 & 0.423 & 0.229 \\
\begin{tabular}{l} 
(Scarabaeidae) \\
\hline
\end{tabular} & & & & \\
\hline
\end{tabular}

Kekayaan Jenis (R) Parasitoid dan Serangga netral serta Dominansi (C) Parasitoid Braconidae dan Serangga netral Scarabaeidae pada Ekosistem Jagung manis dan kacang panjang

Nilai indeks kekayaan jenis parasitoid dan serangga netral pada tanaman jagung manis organik dan konvensional tergolong rendah $(\mathrm{R}<2.5)($ Tabel 2). Kekayaan jenis pada petak jagung manis organik lebih tinggi nilai indeks kekayaan jenisnya daripada petak konvensional, sebaliknya kekayaan jenis per petak kacang panjang konvensional menunjukkan nilai lebih tinggi dibandingkan organik.

Nilai Dominansi kelompok parasitoid dan serangga netral pada masing masing tanaman tergolong rendah karena populasinya sangat sedikit (15.89\%). Meskipun demikian pada tanaman kacang panjang organik, yang mendominasi serangga netral adalah
Kelompok Kumbang dan pada petak konvensional didominasi oleh parasitoid kelompok tabuhan.

Secara umum dapat dikatakan bahwa keberadaan musuh alami baik dari kelompok predator, parasitoid maupun serangga netral merupakan potensi yang cukup penting dalam pengelolaan hama pada tanaman sayuran. Dengan melihat indeks kekayaan jenis dan dominasi yang lebih tinggi pada kondisi organik dibandingkan konvensional menunjukkan bahwa system pertanian organik mampu menkonservasi musuh alami pada ekosistem sayuran.

Tingginya nilai indeks kekayaan jenis (R) Predator pada jagung manis konvensional dan indeks kekayaan jenis parasitoid dan serangga netral pada kacang panjang konvensional diduga karena perlakuan konvensional yang diberikan. Perlakuan 
konvensional yang digunakan menurut kebiasaan petani di Kalampangan yang sebagian sudah menggunakan cara organik yaitu menggunakan pupuk Kandang Kotoran ayam, dan abu bakaran dari gulma. Kondisi ini perlu dipertahankan untuk menjaga kelestraian musuh alami di kelurahan Kalampangan. Mengingat petani di Kalampangan sendiri pemasok sayuran di kota palangka Raya.

Meskipun masih perlu kehati-hatian mengingat perilaku kebiasaan petani dalam usaha meningkatkan produksi tanaman masih tergantung penggunaan pestisida sintetik dalam mengendalilkan hama dan penyakit tanaman. Aplikasi pestisida yang tidak bijaksana akan membunuh musuh alami. Menurut Untung dan Sastromasono (2000) insektisida sintetik mempunyai dampak yang sangat merugikan bagi keanekaragaman hayati serangga termasuk musuh alami.

Predator dan parasitoid merupakan golongan musuh alami hama penting peranannya dalam proses pengendalian hama (Cheng, 1995). Melalui peran serangga sebagai musuh alami, selain membantu manusia dalam usaha pengendalian hama, juga membantu dalam menjaga kestabilan jaring jarring makanan dalam suatu ekositem pertanian. Keberadaan musuh alami dan serangga netral di lahan pertanaman Kalampangan tentunya perlu dijaga dan dilestarikan salah satu diantaranya dengan pemberian perlakuan organik. Hal ini sesuai dengan pendapat Cheng (1995) bahwa penambahan bahan organik dapat meningkatkan keragaman serangga terutama serangga netral. Demikian juga menurut IFOAM (1995) salah satu tujuan dari pertanian organik adalah mendorong dan meningkatkan siklus hidup biologis dalam ekosistem pertanian.

\section{KESIMPULAN}

Berdasarkan hasil dan pembahasan dapat diambil kesimpulan bahwa sayuran organi memiliki potensi untuk dikembangkan dalam upaya konservasi musuh alami dan serangga netral dengan indikator sebagai berikut :
1. Jumlah serangga yang ditemukan pada lahan organik dan konvensional sebanyak 743 individu, yang terdiri dari predator 625 individu (6 ordo, 26 famili), parasitoid 63 (2 ordo, 6 famili) dan serangga netral sebanyak 55 individu (4 ordo,7 famili)

2. Kekayaan jenis predator pada tanaman kacang panjang organik lebih tinggi dibandingkan konvensional $(\mathrm{R}=2.711$ dan 1.811) dan sebaliknya kekayaan jenis pada tanaman jagung manis konvensional lebih tinggi dibandingkan dengan organik $(\mathrm{R}=$ $3.000,2.783$ )

3. Jenis predator yang mendominasi ekosistem tanaman jagung manis dan kacang panjang organik adalah kelompok jangkrik, semut dan kepik, dengan nilai dominansi masing masing sebesar 0.331; 0.465 dan 0.109

4. Kekayaan jenis parasitoid dan serangga netral pada ekosistem jagung manis organik lebih tinggi dibandingkan konvensional $(\mathrm{R}=1.265$ dan 1.193) dan kekayaan jenis kacang panjang konvensional lebih tinggi dibandingkan dengan organik $(\mathrm{R}=1.919$ dan 1.519$)$

5. Jenis serangga netral yang mendominasi ekosistem tanaman kacang panjang organik adalah kelompok kumbang yang merupakan pemakan bahan organik dan serangga parasitoid yang mendominasi ekosistem pada jagung manis konvensional adalah kelompok tabuhan, dengan nilai dominansi masing masing sebesar 0.423 dan 0.444

\section{DAFTAR PUSTAKA}

Badan Litbang Pertanian. 2002 Prospek Pertanian Organik di Indonesia. info@litbang.deptan.go.id. Februari 2013)

Cheng, J. 1995. Arthropod Community Structures in Rice Ecosystem of China. Workshop on Suistainable Insect Pest Management in Tropical 
Rice. Desember 5-7 1995, Bogor, Indonesia.

Hairiah, K. 2003. Pertanian Organik: Suatu Harapan atau Tantangan? Jurusan Tanah. Fakultas Pertanian Universitas Brawijaya, Malang

IFOAM. 2005. www.ifoam.org. (Diunduh pada 11 November 2016).

Margalef, R., 1958. Temporal succession and spatial heterogeneity in phytoplankton. In: Perspectives in Marine biology, Buzzati-Traverso (ed.), Univ. Calif. Press, Berkeley, 323-347 p.

Melhanah, Supriati,L., dan Saraswati, D. 2015. Komunitas arthropoda pada agroekosistem Jagung Manis dan Kacang Panjang dengan dan Tanpa Perlakuan Insektisida di Lahan Gambut. J. Agri Peat 16(1):37-45.
Murdan dan M. Sardjan. 2009. Potensi Sistem Pertanian Organik Dalam Konservasi Musuh Alami (Predator dan Parasitoid) Hama Pada tanaman Sayuran. Crop Agro 2 (1):43-49.

Odum, E. P. 1971. Dasar-Dasar Ekologi. Edisi ketiga. Diterjemahkan oleh $\mathrm{T}$. Samingan, (1998). Gadjah Mada University Press. Yogyakarta. 697 p.

Untung dan Sosromarsono, S. 2000. Keanekaragaman Hayati Arthropoda Predator dan Parasitoid di Indonesia serta Pemanfaatannya. P. 33-45. Soenardjo Et al (Ed) Prosiding Simposium Keanekaragaman Hayati Arthropoda pada Sistem Produksi Pertanian. PEI dan KEHATI. 16-18 Oktober Bogor

Untung, K. 2003. Pengantar Pengelolaan Hama Terpadu. Gadjah Mada University Press. Yogyakarta. 273 p. 